九州大学学術情報リポジトリ

Kyushu University Institutional Repository

\title{
Parameter Identification for Two Conceptual Hydrological Models of Upper Dau Tieng River Watershed in Vietnam
}

Ngoc, Trieu Anh

Laboratory of Water Environment Engineering, Course of Bioproduction Environmental Sciences, Department of Agro-environmental Sciences, Graduate School of Bioresource and Bioenvironmental Sciences, Kyushu University

Chinh, Le Van

Hiramatsu, Kazuaki

Harada, Masayoshi

https://doi.org/10.5109/20329

出版情報 : 九州大学大学院農学研究院紀要. 56 (2)，pp. 335-341，2011-09. 九州大学大学院農学研究院 バージョン：

権利関係 : 


\title{
Parameter Identification for Two Conceptual Hydrological Models of Upper Dau Tieng River Watershed in Vietnam
}

\author{
Trieu Anh NGOC ${ }^{1 *}$, Le Van CHINH, Kazuaki HIRAMATSU \\ and Masayoshi HARADA
}

\author{
Laboratory of Water Environment Engineering, Division of Bioproduction Environmental Sciences, \\ Department of Agro-environmental Sciences, Faculty of Agriculture, \\ Kyushu University, Fukuoka 812-8581, Japan \\ (Received May 6, 2011 and accepted May 9, 2011)
}

\begin{abstract}
Selection of hydrological models to calculate the rainfall runoff for a river watershed with particular characteristics is not an easy task. Especially in recent years, there have been many conceptual hydrological models to calculate rainfall runoff. The study and analysis of hydrological models that are applied under suitable conditions for appropriate watersheds are necessary to improve the accuracy and applicability of each model. In this research, two hydrological models, namely the Tank model and the NAM model, were used to model the rainfall runoff process of the river system upstream of the Dau Tieng River watershed located along the upper Saigon River in southeast Vietnam. Based on the relationship between model parameters and watershed characteristics, a set of preliminary model parameters was found. The final estimation of the optimal parameters was carried out by calibration through comparison between the simulated time series and the observed data of the overall water balance, overall hydrograph shape, peak flows, and low flows.
\end{abstract}

Keywords: Rainfall runoff, river watershed, discharge, peak flow, low flow, hydrological model, simulation

\section{INTRODUCTION}

The lumped conceptual hydrological models have been known since the early 1960s and widely applied since the late 1970s (Boughton, 2005). The models that are still in use today are the Sacramento model (Burnash, 1995), the AWBM model (Boughton, 2004), the Tank model (Sugawara, 1995), the HBV model (Bergström, 1995), and the NAM model (Havnø et al., 1995; Nielsen and Hansen, 1973). However, the application of a model by calculations often faces difficulty due to not only the complexity of model structure, but also the inaccuracy of model parameters. Over the past several decades, many hydrological models have been developed and applied for runoff forecasts of river watersheds with a view to improving the fits of runoff prediction results in a simple way so that parameters are identified reliably through the runoff hydrograph analysis. Once a runoff model is designed, the parameters of the model would be determined in the runoff hydrograph analysis by optimal adjustment of the simulated flow results to the observed flow hydrograph.

Research on the development of appropriate implementation measures with a focus on different aspects of the hydrograph (e.g., different calibration objectives) has been quite satisfactory. Harlin (1991) and Zhang and Lindstrom (1997) formulated automatic routines that apply numerically optimized visual goodness-of-fit measures to infer the course of a manual calibration by expe-

\footnotetext{
Laboratory of Water Environment Engineering, Course of Bioproduction Environmental Sciences, Department of Agroenvironmental Sciences, Graduate School of Bioresource and Bioenvironmental Sciences, Kyushu University

* Corresponding author (E-mail: anhngoc267@yahoo.com)
}

rienced hydrologists focused on the description of different processes. More recently, automatic routines with a general multi-objective-based calibration have been applied to the rainfall runoff model (Lindstrom, 1997; Liong et al., 1998; Gupta et al., 1998; Madsen, 2000; Boyle et al., 2000).

In this study, model parameters of the NAM model (DHI, 1993; DHI, 2007a; DHI, 2007b) and the Tank model (Sugawara, 1995) were calibrated automatically and manually for each simulation using an optimal algorithm until the final appropriate parameters were found. First, the initial parameters of the NAM and Tank conceptual hydrological models were determined from the relationship between runoff and watershed characteristics. The main parameters with high sensitivity were evaluated through a multi-objective review to determine priorities, such as the overall water balance, overall hydrograph shape, peak flows, and low flows. Next, the automatic calibration algorithm was combined with a compilation of VBA (Visual Basic for Applications) code and a Microsoft Excel add-in method (solver.xla). This was then manually calibrated to produce simulated flow results in conformity as much as possible with the observed flow.

This paper aims to apply the aforesaid two models to a simulation of the outlet flow of the Dau Tieng River watershed of the upper Saigon River without knowing their initial parameters. In that sense, this research concentrates on analysis and adjustment measures to determine optimal model parameters through accurate watershed runoff calculations in order to evaluate the appropriateness and applicability of each model under particular watershed conditions. 


\section{MATERIALS AND METHODS}

\section{Study area}

The Dau Tieng River watershed is located along the

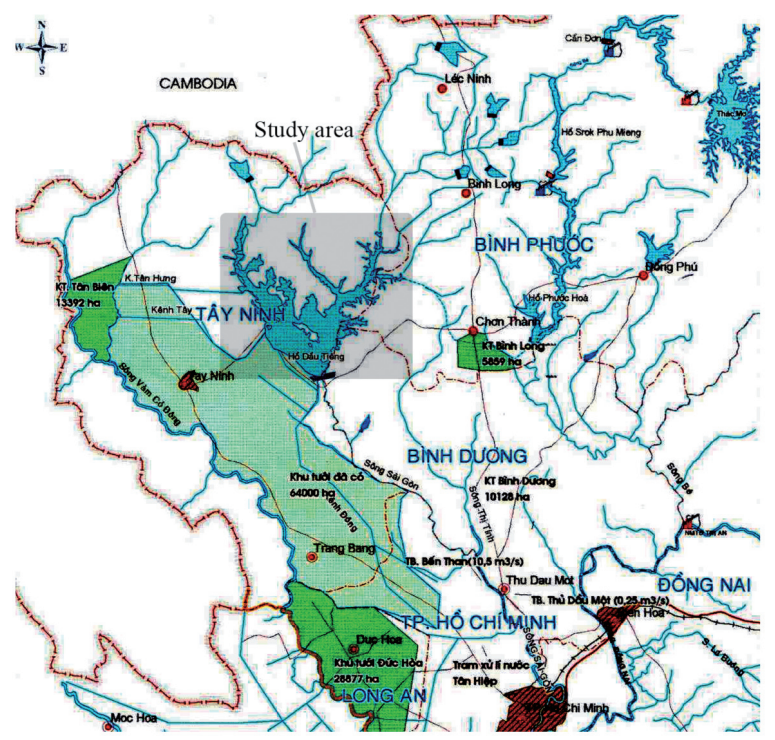

Fig. 1. Location of Dautieng River watershed.

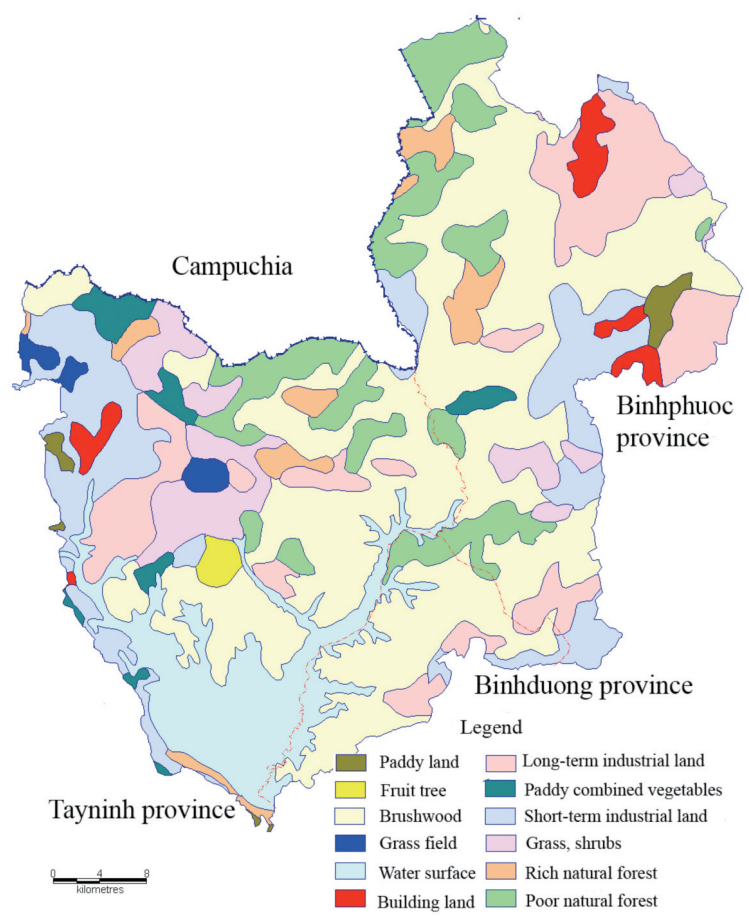

Fig. 2. Map of land use in Dau Tieng River watershed. upper Saigon River in Tay Ninh Province in southeast Vietnam. It is a main reach of the upper Saigon-Dongnai River system as shown in Fig. 1. The watershed is mainly covered with brushwood, forest, and industrial cropland as shown in Fig. 2, and the total area of the watershed is about $2,700 \mathrm{~km}^{2}$. The upper Saigon reach comes from Cambodian river branches and discharges into the downstream portion of the Saigon-Dongnai River system. The Dau Tieng Reservoir in the watershed area is well known as the largest reservoir for irrigation in Vietnam, with a river slope of $0.25 \%$ and a total length of $130.5 \mathrm{~km}$. The water stored in the Dau Tieng Reservoir is utilized not only for irrigating the downstream agricultural area, but also for preventing saltwater intrusion and maintaining freshwater discharge into the river. The elevation of the watershed area is typically from $+24 \mathrm{~m}$ to $+100 \mathrm{~m}$, with annual rainfall of about $1800 \mathrm{~mm}$.

\section{Data}

The data on the Dau Tieng River watershed that were used in this research were recorded during the years 1978 to 2008 at three rainfall gauge stations and one discharge gauge station. These data were collected from the Dau Tieng Irrigation Exploitation and Management Company under the Ministry of Agriculture and Rural Development, Vietnam. The daily rainfall data collected from each station were not uniformly distributed through-

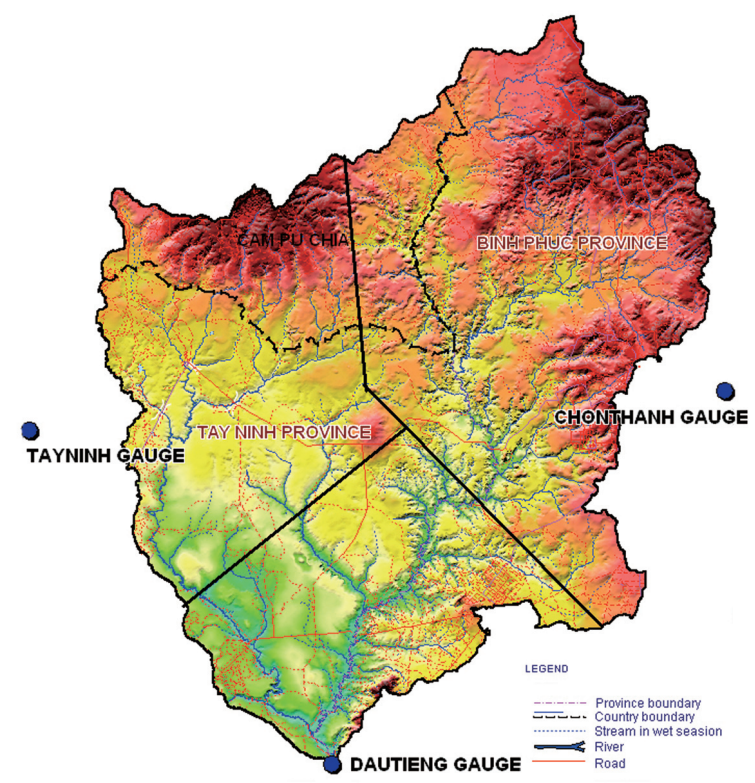

Fig. 3. 90-m DEM of Dau Tieng River watershed and locations of gauge stations

Table 1. Rainfall data of each rain gauge station (see also Fig. 3)

\begin{tabular}{|c|c|c|c|c|c|c|c|}
\hline Basin & Station & $\begin{array}{c}\text { Sub-catchment } \\
\text { Area }\left(\mathrm{Km}^{2}\right)\end{array}$ & $\begin{array}{l}\text { Thiessen } \\
\text { Weight }\end{array}$ & $\mathrm{N}$ & $\mathrm{E}$ & Data type & Year \\
\hline \multirow{5}{*}{$\begin{array}{l}\text { Dautieng } \\
\text { River } \\
\text { watershed }\end{array}$} & Tayninh & 810 & 0.3 & $11^{\circ} 40^{\prime} 33^{\prime \prime}$ & $106^{\circ} 13^{\prime} 15^{\prime \prime}$ & Rainfall & $1978-2008$ \\
\hline & Chonthanh & 810 & 0.3 & $11^{\circ} 23^{\prime} 54^{\prime \prime}$ & $106^{\circ} 38^{\prime} 31^{\prime \prime}$ & Rainfall & $1978-2008$ \\
\hline & & & & & & Rainfall & 1878-2008 \\
\hline & Dautieng & 1080 & 0.4 & $11^{\circ} 5^{\prime} 39^{\prime \prime}$ & $106^{\circ} 22^{\prime} 32^{\prime \prime}$ & Evaporation & 1878-2008 \\
\hline & & & & & & Discharge & 1978-2008 \\
\hline
\end{tabular}


out the Dau Tieng River watershed; therefore, a Thiessen polygon method was used to obtain the average watershed rainfall. The location and data of each rainfall gauge station are shown in Fig. 3 and Table 1.

\section{NAM model}

The hydrological NAM model simulates the rainfall runoff processes that occur at the watershed scale. The NAM model forms part of the rainfall runoff module of the MIKE 11 river modeling system. It was originally developed at the Institute of Hydrodynamic and Hydraulic Engineering at the Technical University of Denmark (Nielsen and Hansen, 1973; Havnø et al., 1995; Madsen, 2000). The NAM model considers nine parameters and represents various components of the rainfall runoff process by continuously accounting for the water content

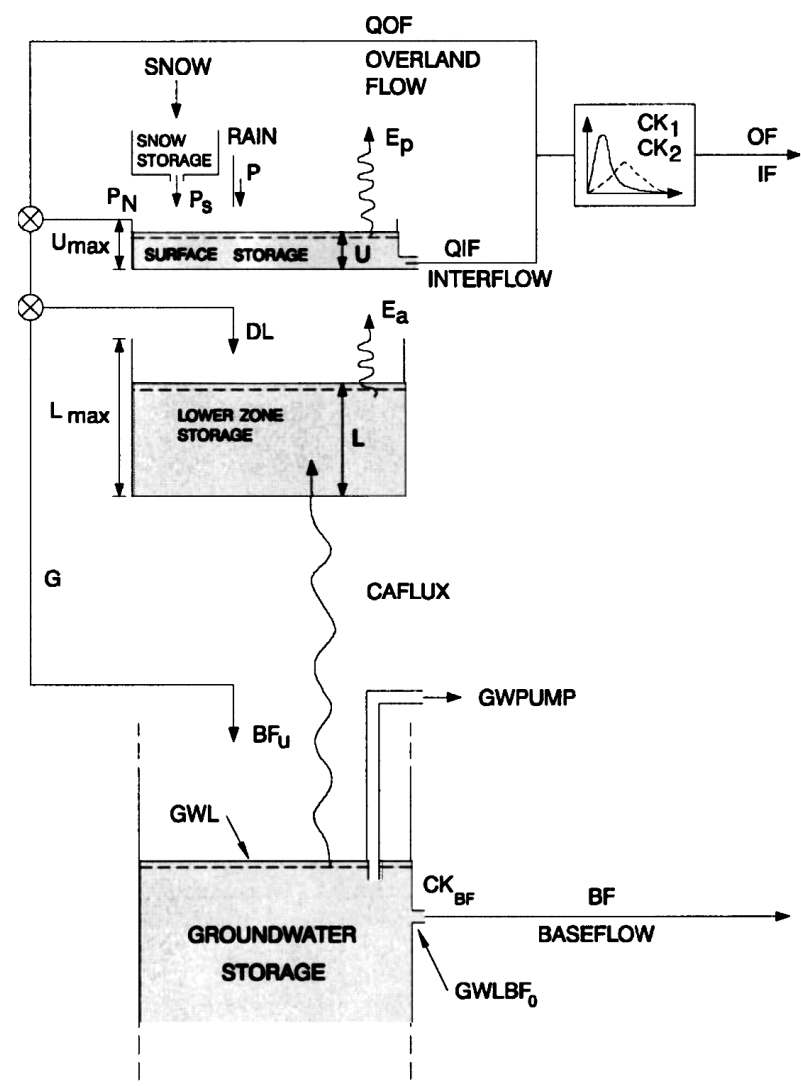

Fig. 4. Structure of the NAM model (see also Table 2). in four different but mutually interrelated forms of storage: snow, surface, lower zone, and groundwater storage. The routine for overland flow, interflow, and baseflow shown in Fig. 4 is also based on the linear reservoir.

Based on the meteorological data input, the NAM model produces the watershed runoff as well as information about other elements of the land phase of the hydrological cycle, such as the temporal variation of the evapotranspiration, soil moisture content, groundwater recharge, and groundwater levels. The resulting watershed runoff is conceptually split into overland flow, interflow, and baseflow components (DHI, 2007b)

\section{Tank model}

The Tank model is a synthetic flow model based on the rainfall in a watershed. This was developed and introduced in 1956 by Japanese hydrologist Dr. Masami Sugawara, who is also the author of many works published about his research and its practical applications. This model has been widely used throughout the world and evaluated as good by the World Meteorological Organization (WMO). The Tank model can be applied

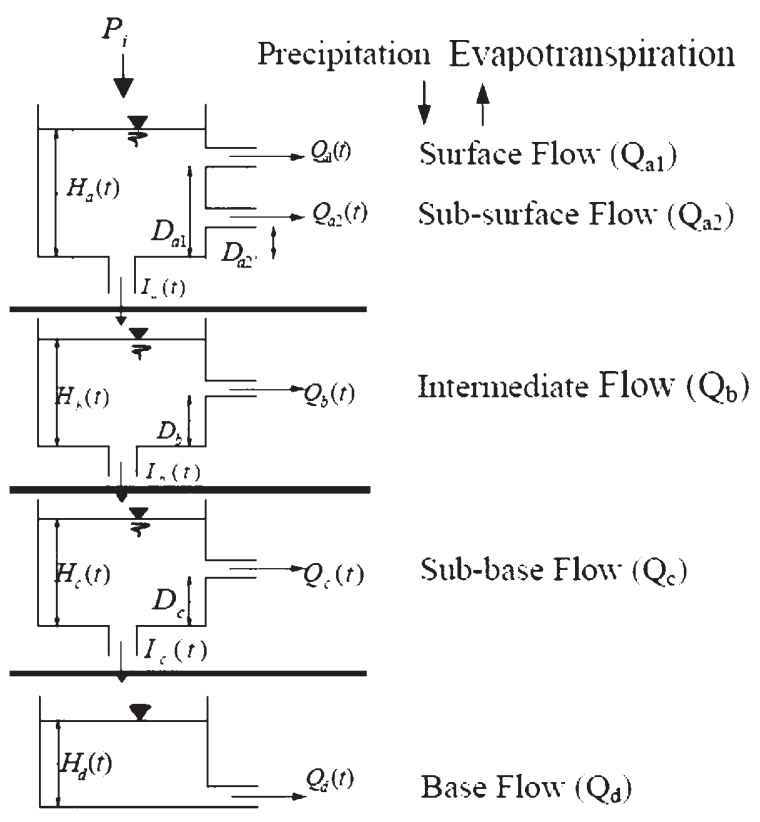

Fig. 5. Structure of the Tank model.

Table 2. NAM model parameters and hypercube search space (DHI, 2007a) (see also Fig. 4)

\begin{tabular}{|c|c|c|c|}
\hline Parameter & Description & Lower limit & Upper limit \\
\hline$U_{\max }(\mathrm{mm})$ & The maximum water content in surface storage & 5 & 35 \\
\hline$L_{\max }(\mathrm{mm})$ & The maximum water content in root zone storage & 50 & 350 \\
\hline$C Q_{\mathrm{CF}}(-)$ & Overland flow runoff coefficient & 0 & 1 \\
\hline$C K_{1,2}$ (hour) & The time constant for routing interflow and overland flow & 3 & 72 \\
\hline$T_{\mathrm{OF}}(-)$ & Root zone threshold value for overland flow & 0 & 0.9 \\
\hline$T_{\mathrm{IF}}(-)$ & Root zone threshold value for interflow & 0 & 0.9 \\
\hline$T_{\mathrm{G}}(-)$ & Root zone threshold value for groundwater & 0 & 0.9 \\
\hline$C K_{\mathrm{BF}}$ (hour) & Time constant for routing base-flow & 500 & 5000 \\
\hline$C K_{\mathrm{IF}}$ (hour) & Time constant for routing interflow & 500 & 1000 \\
\hline
\end{tabular}


Table 3. Tank model parameters used for calibration (Gunawan, 2010)

\begin{tabular}{cllcc}
\hline Coeficient & \multicolumn{1}{c}{ Functions } & Description & Lower limit Upper limit \\
\hline$C_{\mathrm{a} 1}$ & $Q_{\mathrm{a} 1(t)}=C_{\mathrm{a} 1} \times\left(H_{\mathrm{a}(t)}-D_{\mathrm{a} 1}\right)$ & Surface runoff coefficient & 0 & 1 \\
$C_{\mathrm{a} 2}$ & $Q_{\mathrm{a}(t)}=C_{\mathrm{a} 2} \times\left(H_{\mathrm{a}(t)}-D_{\mathrm{a} 2}\right)$ & Sub-surface runoff coefficient & 0 & 1 \\
$C_{\mathrm{a} 0}$ & $I_{\mathrm{a}(t)}=C_{\mathrm{a} a} \times H_{\mathrm{a}(t)}$ & Infiltration coefficient & 0 & 1 \\
$C_{\mathrm{b} 1}$ & $Q_{\mathrm{b}(t)}=C_{\mathrm{b} 1} \times\left(H_{\mathrm{b}(t)}-D_{\mathrm{b}}\right)$ & Intermediate runoff coefficient & 0 & 1 \\
$C_{\mathrm{b} 0}$ & $I_{\mathrm{b}(t)}=C_{\mathrm{b} 0} \times H_{\mathrm{b}(t)}$ & Infiltration coefficient & 0 & 1 \\
$C_{\mathrm{c} 1}$ & $Q_{\mathrm{c}(t)}=C_{\mathrm{c} 1} \times\left(H_{\mathrm{c}(t)}-D_{\mathrm{c}}\right)$ & Sub-base runoff coefficient & 0 & 1 \\
$C_{\mathrm{c} 0}$ & $I_{\mathrm{c}(t)}=C_{\mathrm{c} 0} \times H_{\mathrm{c}(t)}$ & Infiltration coefficient & 0 & 1 \\
$C_{\mathrm{d} 1}$ & $Q_{\mathrm{a}(t)}=C_{\mathrm{a} 1} \times H_{\mathrm{d}(t)}$ & Base runoff coefficient & 0 & 1 \\
$D_{\mathrm{a} 1}$ & & Height of upper surface outlet & 0 & 100 \\
$D_{\mathrm{a} 2}$ & & Height of sub-surface outlet & 0 & 100 \\
$D_{\mathrm{b}}$ & & Height of intermediate outlet & 0 & 100 \\
$D_{\mathrm{c}}$ & & Height of sub-base outlet & 0 & 100 \\
\hline
\end{tabular}

not only to reproduce the stream flow from the observed rainfall data of the watershed, but also to forecast the flood flow to serve the planning, design, and management of water resources. In Vietnam, the Tank model has been applied in researches and is considered fairly suitable for river and stream systems.

The typical Tank model is designed with four tanks, consisting of a surface tank (A), intermediate tank (B), sub-base tank (C), and base tank (D). The main input of the model is the amount of rainfall that remains on the watershed after the amount of water removed by the evapotranspiration process has been deducted. Two assumptions of the Tank model are that water is able to fill the storage that lies beneath and that water flows from a horizontal outlet in each tank, which is represented as outflow.

A vertically structured model is used for the wet area of the watershed. Each tank has a vertical outlet at the bottom (except Tank D) and one horizontal outlet at the side (except Tank A, which typically has two). Rainwater falls into Tank A and then partly through the vertical outlet into the tank below. The remainder of the rainwater pours into the horizontal outlets to create flow. However, rainwater is released through a horizontal outlet only when the level of water in the tank is greater than the height of a horizontal outlet (Gunawan, 2010).

The total outflow (Q) from the side outlets of all tanks represents the accumulation of the outflows from the river system in the watershed, and this can be expressed as follows:

$$
Q_{(t)}=\left\{Q_{\mathrm{a} 1(t)}+Q_{\mathrm{a} 2(t)}+Q_{\mathrm{b}(t)}+Q_{\mathrm{c}(t)}+Q_{\mathrm{d}(t)}\right\}
$$

The water balance equation is then

$$
\frac{d}{d t} H_{(t)}=P_{(t)}-E_{(t)}-Q_{(t)}
$$

where $P$ is rainfall (mm/day), $E$ is evapotranspiration (mm/day), $Q$ is total runoff (mm/day), $H$ is water storage level (mm), and $t$ is time step (day). At the initial time $(t=1)$, the initial conditions of the water levels in the storage tanks A, B, C, D are given (as $H_{\mathrm{a} 1}, H_{\mathrm{b} 1}, H_{\mathrm{c} 1}, H_{\mathrm{d} 1}$ ).
For the next step $(t+1)$, the storage in each tank is updated as follows:

$$
\begin{aligned}
& H_{\mathrm{a}(t+1)}=H_{\mathrm{a}(t)}+P_{(t)}-Q_{\mathrm{al}(t)}-Q_{\mathrm{b}(t)}-I_{\mathrm{a}(t)} \\
& H_{\mathrm{b}(t+1)}=H_{\mathrm{b}(t)}+I_{\mathrm{a}(t)}-Q_{\mathrm{b}(t)}-I_{\mathrm{b}(t)} \\
& H_{\mathrm{c}(t+1)}=H_{\mathrm{c}(t)}+I_{\mathrm{b}(t)}-Q_{\mathrm{c}(t)}-I_{\mathrm{c}(t)} \\
& H_{\mathrm{d}(t+1)}=H_{\mathrm{d}(t)}+I_{\mathrm{c}(t)}-Q_{\mathrm{d}(t)}
\end{aligned}
$$

\section{Formulation of multi-objective calibration}

Parameters in the models were chosen within the ranges listed in Tables 2 and 3. The automatic calibration routine is based on a multi-objective optimization strategy whereby the following calibration objectives can be optimized simultaneously:

1. Agreement between the average simulated and observed watershed runoffs

2. Good overall agreement of the hydrograph shapes

3. Good agreement of the peak flows with respect to timing, rate, and volume

4. Good agreement for low flows

The correlation coefficient $\left(R^{2}\right)$, peak error, volume error, and wave errors are used to evaluate the goodnessof-fit of the simulated hydrograph. The detailed formula is given in the MIKE 11 reference manual (DHI, 2007b).

\section{RESULTS AND DISCUSSION}

\section{Optimization process}

Automatic calibration with the initial parameter values of the models yielded the discharge data for a fiveyear period from 1978 to 1982 . The simulated flow was then compared with the flow observed at the Dau Tieng gauge station for those years. The deviation of the simulated flow from the observed flow was evaluated on the basis of a multi-objective optimization strategy, as mentioned above.

As the model conformity improves, $R^{2}$ approaches unity. The results of the Tank model of the Dau Tieng River watershed reached good agreement with the fiveyear calibration data, since the efficiencies ranged from 


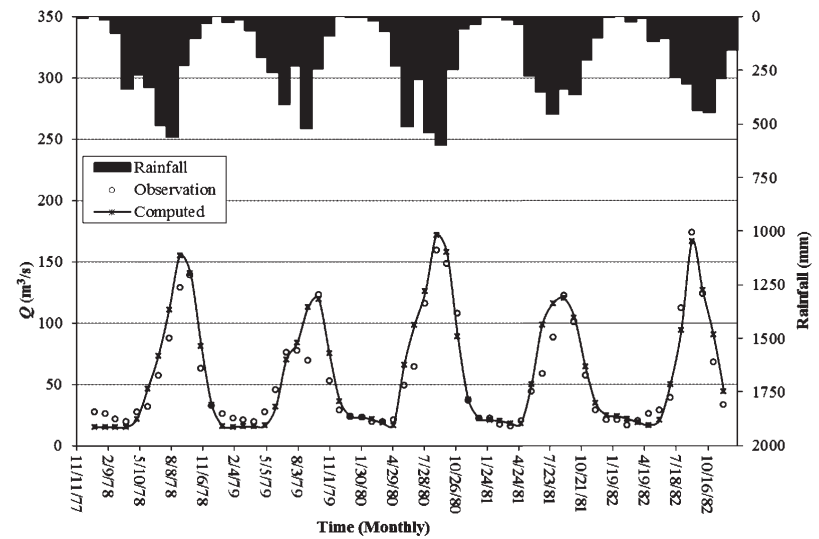

Fig. 6. Comparison between observed and simulated flows in 1978-1982 with the Tank model.

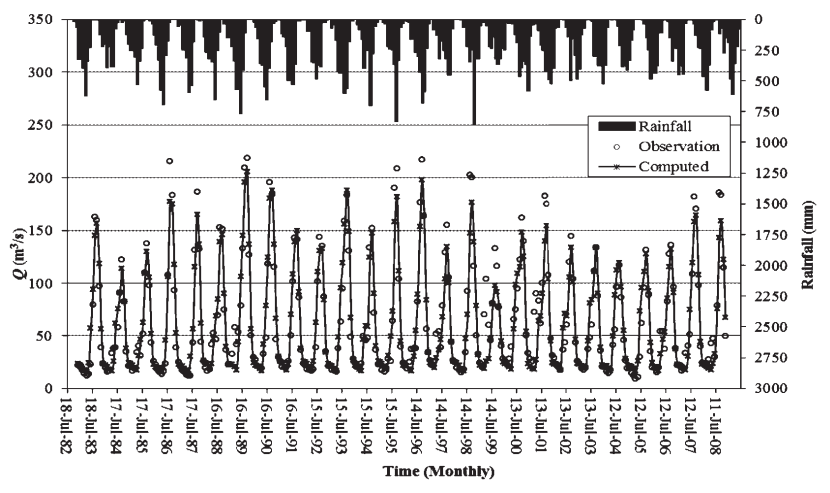

Fig .7. Comparison between observed and simulated flows in 1983-2008 with the Tank model.

Table 4. Statistics of the NAM and Tank models for Dau Tieng River watershed

\begin{tabular}{|c|c|c|c|c|c|}
\hline \multirow[b]{2}{*}{ Case } & \multirow[b]{2}{*}{ Units } & \multicolumn{2}{|c|}{ NAM } & \multicolumn{2}{|c|}{ TANK } \\
\hline & & $\begin{array}{l}\text { Calibration } \\
1978-1982\end{array}$ & $\begin{array}{l}\text { Verification } \\
\text { 1983-2008 }\end{array}$ & $\begin{array}{l}\text { Calibration } \\
\text { 1978-1982 }\end{array}$ & $\begin{array}{l}\text { Verification } \\
\text { 1983-2008 }\end{array}$ \\
\hline Correlation coefficient & $\%$ & 0.92 & 0.95 & 0.95 & 0.97 \\
\hline Peak error & $\%$ & -0.18 & -0.21 & 0.01 & -0.06 \\
\hline Wave error type 1 & $\%$ & 0.017 & 0.008 & 0.007 & 0.003 \\
\hline Wave error type 2 & $\%$ & 0.19 & 0.141 & 0.308 & 0.152 \\
\hline Volume error & $\%$ & 0.295 & 0.225 & 0.242 & 0.182 \\
\hline Max. positive difference & $\mathrm{m}^{3} / \mathrm{s}$ & 70.607 & 88.653 & 14.98 & 13.985 \\
\hline Max. negative difference & $\mathrm{m}^{3} / \mathrm{s}$ & 38.302 & 62.254 & 15 & 14.00 \\
\hline Qmax(observed) & $\mathrm{m}^{3} / \mathrm{s}$ & 173.71 & 218.29 & 173.71 & 218.29 \\
\hline Qmax(simulated) & $\mathrm{m}^{3} / \mathrm{s}$ & 162.85 & 225.55 & 171.75 & 205.34 \\
\hline
\end{tabular}

Table 5. Calibrated parameters of the Tank model

\begin{tabular}{lcc}
\hline Coeficient & Period of 1978-1982 & Period of 1983-2008 \\
\hline$C_{\mathrm{a} 1}$ & 0.33 & 0.28 \\
$C_{\mathrm{a} 2}$ & 0.01 & 0.01 \\
$C_{\mathrm{a} 0}$ & 0.22 & 0.24 \\
$C_{\mathrm{b} 1}$ & 1.00 & 0.90 \\
$C_{\mathrm{b} 0}$ & 1.00 & 0.89 \\
$C_{\mathrm{c} 1}$ & 0.26 & 0.64 \\
$C_{\mathrm{c} 0}$ & 1.00 & 1.00 \\
$C_{\mathrm{d} 1}$ & 0.90 & 0.90 \\
$D_{\mathrm{a} 1}(\mathrm{~mm})$ & 10.12 & 10.13 \\
$D_{\mathrm{a} 2}(\mathrm{~mm})$ & 53.87 & 53.87 \\
$D_{\mathrm{b} 1}(\mathrm{~mm})$ & 28.12 & 28.00 \\
$D_{\mathrm{c} 1}(\mathrm{~mm})$ & 20.00 & 20.00 \\
\hline
\end{tabular}

0.95 to 0.97 . All the appropriate statistics for 5 years are listed in Table 4. Compatibility was found between the hydrograph shapes of the simulated flow and the observed flow, with the same peak time and similar peak values $\left(Q_{\text {max,obs }}=157.44 \mathrm{~m}^{3} / \mathrm{s}\right.$ and $Q_{\text {max }, \text { sim }}=171.75 \mathrm{~m}^{3} / \mathrm{s}$ for 1980$)$, as shown in Fig. 5.

Calibrated parameters were used in the Tank model for verification with a 25-year period. Though less satisfactory than those listed in Table 4, the results were fairly good, having a correlation coefficient of 0.97 , peak error of -0.06 , volume error of 0.18 , and wave error aver-
Table 6. Calibrated parameters of the NAM model

\begin{tabular}{lrr}
\hline Parameter\Period & $1978-1982$ & $1983-2008$ \\
\hline$U_{\max }(\mathrm{mm})$ & 15.30 & 15.20 \\
$L_{\max }(\mathrm{mm})$ & 287.00 & 287.00 \\
$C Q_{\mathrm{OF}}$ & 0.22 & 0.22 \\
$C K_{\mathrm{IF}}$ (hours) & 634.90 & 632.10 \\
$C K_{1,2}$ (hours) & 17.90 & 17.50 \\
$T_{\mathrm{OF}}$ & 0.99 & 0.98 \\
$T_{\mathrm{IF}}$ & 0.86 & 0.85 \\
$T_{\mathrm{G}}$ & 0.17 & 0.17 \\
$C K_{\mathrm{BF}}$ (hours) & 1047.00 & 1028.00 \\
\hline
\end{tabular}

age of 0.075 . The Tank model was successfully applied to predict the discharge of the Dau Tieng River watershed when all parameters were directly estimated on the basis of the relationship between watershed characteristics and model parameters (see Table 5).

Automatic calibration for the NAM model of the Dau Tieng River watershed was also realized for the five-year period from 1978 to 1982 . However, although $R^{2}$ ranged from 0.92 to 0.95 , agreement between the simulated flow and the observed flow was not reached, because errors in the peak flow time and volume flow are weighted heavily for a flood and were too high (e.g., maximum peak error of $29.5 \%$ in1979). The statistical assessment of the NAM results and the model parameters are listed 


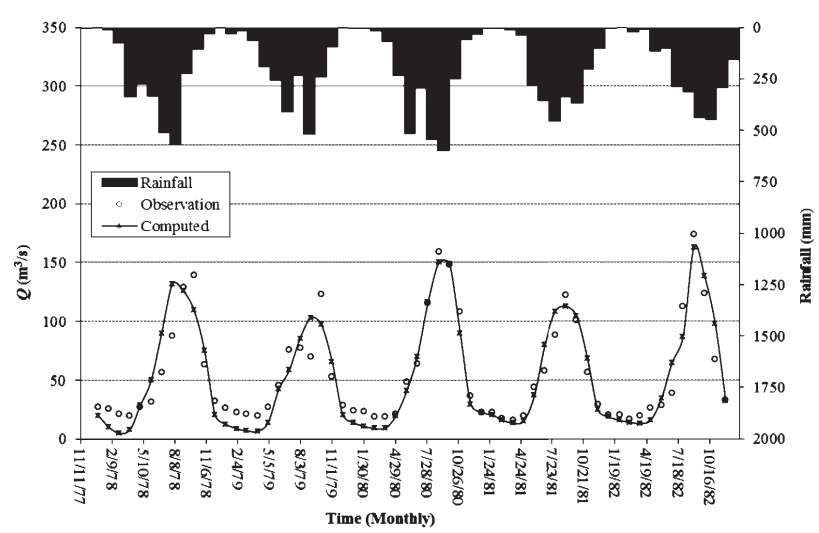

Fig. 8. Comparison between observed and simulated flows in 1978-1982 with the NAM model.

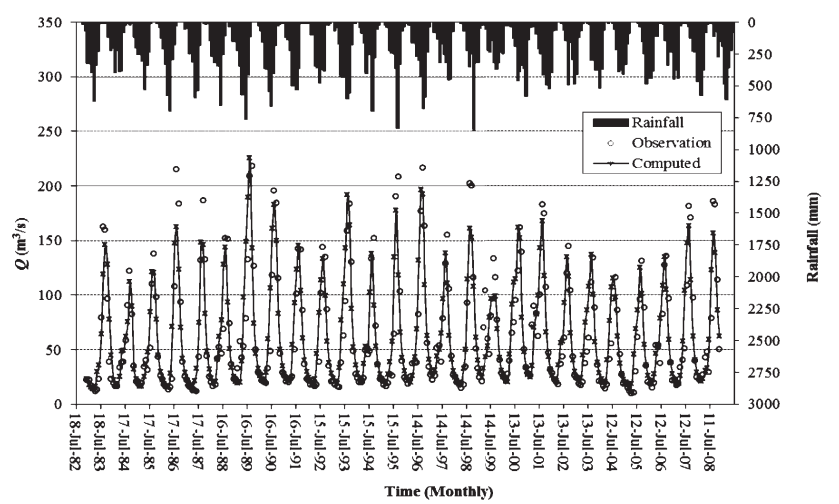

Fig. 9. Comparison between observed and simulated flows in 1983-2008 with the NAM model.

in Table 4 and Table 6 , respectively.

\section{Comparison between observed flow and simulated flow}

As shown in Fig. 10, the NAM model was less accurate than the Tank model. This is demonstrated by two peak flows in the years 1978 and 1979. The simulated peak flow of the NAM model was delayed in comparison with the observed peak flow. However, the Tank model led to good agreement between the hydrograph of the simulated flow and that of the observed flow, with the same peak time and similar peak values, as seen in Figs. 10 and 11.

\section{For further study}

In this study, the data used were from only three rainfall gauge stations. To design a better rainfall runoff simulation using the Tank model and calculate the results, data are required from many rainfall gauge stations that represent the entire watershed. Furthermore, good quality rainfall data for storm events are necessary. The initial parameters of the Tank model in this study were determined before the optimization process started and then adjusted manually. To obtain accurate simulated results for characteristics that are spatially varying, there is a need to divide a large watershed, such as that of the Dau Tieng River, into many sub-watersheds. Therefore,

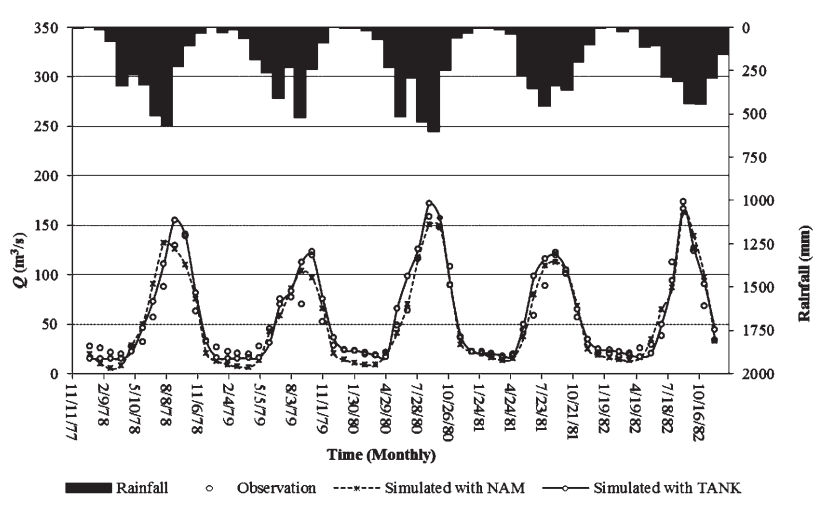

Fig. 10. Comparison between observed and simulated flows in 1978-1982.

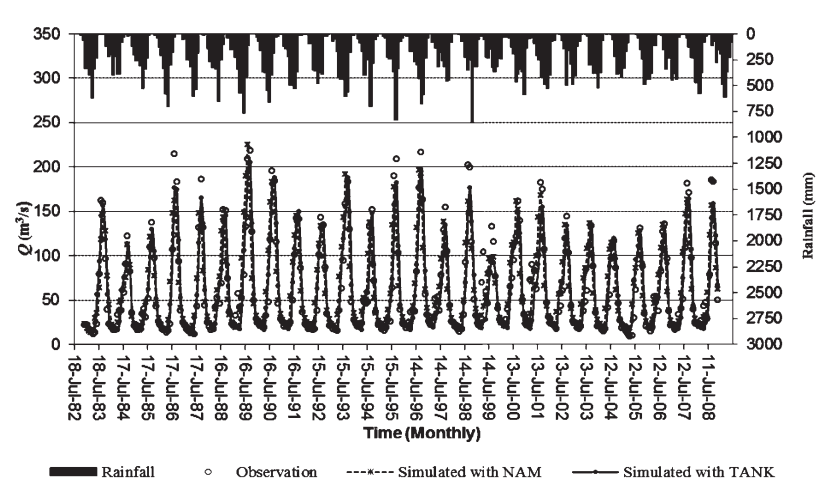

Fig. 11. Comparison between observed and simulated flows in 1983-2008.

further studies may adopt the compound Tank model to calculate the rainfall runoff of each sub-watershed. Additionally, when incorporated with a genetic algorithm (GA) for optimization, the Tank model will produce more appropriate simulation results through calibration of the optimization algorithm to determine the best parameters.

\section{Conclusion}

In this study, using meteorological data for the period 1978-2008, the NAM and Tank models the of the physical characteristics of the Dau Tieng River watershed were calibrated to produce good agreement in comparisons between the hydrograph shapes of the simulated flow and the observed flow. A calibration process with automatic and manual steps was applied to 8645 rainfall and runoff data. To run models and provide results took a long time, as the settings of 12 parameters in the Tank model and 9 parameters in the NAM model were adjusted. According to the results for the runoff that occurs every year in Dau Tieng River watershed, the final parameters of the two models were appropriate. That is, the simulated runoff results were very satisfactory, with minimum error and high efficiency $\left(R^{2}>0.9\right)$.

However, an automatic calibration scheme for the two models has been formulated that considers the calibration problem in a general multi-objective framework. 
This scheme optimizes the numerical performance measures of four different calibration objectives, which involve overall water balance, overall hydrograph shape, peak flows, and low flows. In practical applications, the user can select any combination of the four objective functions, depending on the objectives of the specific model application considered (Madsen, 2000). Therefore, the selection of objectives for calibration is not a simple issue and is very reliant on experienced hydrologists.

A combination of automatic calibration with manual calibration often gives more precise solutions. The abovementioned four targets were considered concurrently until a set of parameters was found that provided an excellent simulation of the runoff volume or the water balance yet with an unsatisfactory peak discharge. Accordingly, manual calibration should be done afterward in order to ensure a good simulation of all targets.

Many different sets of parameters may result in similarly good agreement with the data series, so whether one is better overall may be difficult to define. For this reason, selection of the optimal parameter set for the observed data of a certain period may not be ideal for that of another period.

\section{ACKNOWLEDGEMENTS}

The authors would like to thank the Institute for Water Resources \& Environment, the Division of Applied Science \& Technology of the Water Resources University - Second Campus, and the Dau Tieng Irrigation Exploitation and Management Company for supplying hydrometeorological and operation process data.

\section{REFERENCES}

Bergstrom, S. 1995 The HBV model. In "Computer Models of Watershed Hydrology" ed. by V. P. Singh, Water Resources Publications, Colorado, pp. 443-476

Burnash, R. J. C. 1995 The NWS river forecast system catchment modeling. In "Computer Models of Watershed Hydrology" ed. by V. P. Singh, Water Resources Publications, Colorado, pp. 311-366

Boughton, W. C. 2004 Adaptation of the AWBM for estimating runoff from ungauged catchments. Australian Journal of Water Resources, $8(2)$ : 123-132

Boughton, W. C. 2005 Catchment water balance modeling in Australia 1960-2004. Agricultural Water Management, 71(2): 91-116

Boyle, D. P., H. V. Gupta and S. Sorooshian 2000 Toward improved calibration of hydrological models: combining the strengths of manual and automatic methods. Water Resources Research, 36(12): 3663-3674

DHI 1993 MIKE 11/NAM short description. DHI Water and Environment, Demark, pp. 101-103

DHI 2007a MIKE 11 user manual. DHI Water and Environment, Demark, pp. 229-244

DHI 2007b MIKE 11 reference. DHI Water and Environment, Demark, pp. 290-325

Gupta, H. V., S. Sorooshian and P. O. Yapo 1998 Toward improved calibration of hydrological models: multiple and noncommensurable measures of information. Water Resources Research, 34(4): 751-763

Gunawan, S. 2010 Research on development of rainfall runoff model for Bogowonto River basin by using tank model. International Centre for Water Hazard and Risk Management: http://www.icharm.pwri.go.jp/training/master/pubilication/ pdf/2010/gunawan.pdf

Havnø, K., M. N. Madsen and J. Dørge 1995 MIKE-11 a generalized river modelling package. In "Computer Models of Watershed Hydrology" ed. by V. P. Singh, Water Resources Publications, Colorado, pp. 733-782

Harlin, J. 1991 Development of a process oriented calibration scheme for the HBV hydrological model. Nordic Hydrology, 2: $15-36$

Lindstrom, G. 1997 A simple automatic calibration routine for the HBV model. Nordic Hydrology, 28(3): 153-168

Liong, S. Y., S. T. Khu and W. T. Chan 1998 Derivation of Pareto front with accelerated convergence genetic algorithm, ACGA. In "Hydroinformatics" ed. by V. Babovic and L. C. Larsen, Balkema, Rotterdam, Netherlands, pp. 889-896

Madsen, H. 2000 Automatic calibration of a conceptual rainfall runoff model using multiple objectives. Journal of Hydrology, 235: 276-288

Nielsen, S. A. and E. Hansen 1973 Numerical simulation of the rainfall runoff process on a daily basis. Nordic Hydrology, 4: $171-190$

Sugawara, M. 1995 Tank model. In "Computer Models of Watershed Hydrology" ed. by V. P. Singh, Water Resources Publications, Colorado, pp. 165-214

Zhang, X. and G. Lindstrom 1997 Development of an automatic calibration scheme for the HBV hydrological model. Hydrology Process, 11: 1671-1682 